Yale Industrial Forestry Seminar at Seattle during the week October 23-27, 1961.

The Seminar will be on the topic "Financial Management of Large Forest Ownerships" and each of the five days will be devoted to a discussion of some phase of this topic under outstanding leaders in the field. Two of these men are Robert V. Hansberger, President of Boise Cascade Corporation and John Fedkiw, Forest Economist at the Pacific Northwest Forest Experiment Station.

Enrollment in the Seminar is limited to twenty men whose experience will qualify them for participation.

For additional information write to:

Professor Z. W. White, Yale School of Forestry

205 Prospect Street, New Haven 11, Conn.

or

Dean Gordon D Marckworth, College of Forestry,

University of Washington, Seattle 5, Washington.

\title{
Classification and Cataloguing of Forestry Film Material
}

The form of catalogue recommended by the Joint FAO/IUFRO Committee on Bibliography and approved by the European Forestry Commission's Tenth Session is a card system based on the Oxford Decimal Classification and maintained separately from any other catalogue, embodying the following features. The cards should be filed at least:

1. according to the ODC coding for their subject matter.

2. according to the ODC coding for the country producing the film; but many centers may, in addition, want:

3. to file according to physical locality also, i.e. according to the country in which the film is taken, and

4. to subdivide this by the subject matter.

It is suggested that the cards prepared for filing under (1) and (2) above be white and cards under (3) and (4) tinted, and that due regard be paid to the precepts embodied in the Introduction to the ODC, especially Section 5 .

An example of the information that should be available on a standard $127 \times 75$ millimeters ( $5 \times 3$ inches) card for a film made, for instance, in Yugoslavia by a German producing agency on the general subject of forest regeneration and the transport problems involved, is given below:

23: $37: \quad(497.1)$

Title: (in original language, with translation in either English, French, German or Spanish).

Synopsis: (in original language, with translation on back of card if space on front does not allow for this).

Producer:

Distributor:

$\begin{array}{lcc}\text { Date: } & \text { Length (in min.) } & \text { Width (in mm.) } \\ \text { Language versions: } & \text { Sound } & \text { Color }\end{array}$

Language versions: $\quad$ Sound
Price (local currency): (a) for purchase (b) for hire

Audience: Schools - General - Technical

Clearance for use on television: 
The ODC coding in the top left-hand corner consists, in the above example, of three sets of subheads: 23, regeneration and formation of stands; 37, transport; (497.1) the auxiliary number indicating the physical locality filmed, here in Yugoslavia.

The ODC coding in the top right-hand corner is that of the producer or filming country (here Germany) preceded by the "form" number for films (084.122).

Extract from UNASYLVA, Vol. 14 No. 2, 1960 discussing joint FAO/IUFRO Committee Report on Bïbiliography.

\section{For the Sake of Argument LETTERS TO THE EDITOR}

In his comment (For. Chron., 37:72) on "Of What Cutting Practice Standard is Clearcutting?" (For. Chron., 36:145), Mr. Bethlahmy apparently disagrees with his employer, the United States Forest Service. In the five standards of cutting practice adopted by the Forest Service in 1946, clearcutting was classed as:

(a) Fair, if the land will be restocked to a new forest not inferior to the one removed.

(b) Poor, if the cutting deteriorates the stand in quality and species but reproduces stands of some usable species and quality.

(c) Destructive, where the cutting is over large areas without advance growth or where most of the advance growth is destroyed in logging, without provision for early restocking to commercial species (For. Chron., 36:140).

Mr. Bethlahmy's statement that the clearcutting of forests is equivalent to the clearcutting of planted farm crops seems incorrect unless tree-planting follows the forest cutting, as planting follows harvesting of farm crops. Further, high order agriculture usually includes cultural treatments between planting and harvesting. Clearcutting of forests followed by planting and subsequent cultural measures would certainly be good forestry. Even clearcutting of Douglas fir followed by good regeneration might be classed as high order, provided adequate cultural measures are subsequently undertaken.

High order forestry requires the best types of harvest cuttings, which may include clearcutting in some cases, with cultural measures to build up growing stock to maximum productivity. Clearcutting without cultural measures prior to the cut or in the new stand following the cut, even where the land restocks to a new forest not inferior to the one removed, is only of the fair standard. However, this is the best forestry that can be economically practised in many forests under present conditions. It is also true that picking uncultivated blueberries without destroying the bushes is the best horticulture that can be practised economically on many wild land areas.

R. S. JOHNSON 